\title{
Cadmium and lead levels in three freshwater fish species from the Zambezi region, Namibia
}

\author{
O Madzingira , LZ Lifumbela , E Kandiwa , L Kandjengo \& B Mushonga
}

To cite this article: O Madzingira , LZ Lifumbela , E Kandiwa , L Kandjengo \& B Mushonga (2020):

Cadmium and lead levels in three freshwater fish species from the Zambezi region, Namibia, African Journal of Aquatic Science, DOI: 10.2989/16085914.2020.1732288

To link to this article: https://doi.org/10.2989/16085914.2020.1732288

曲 Published online: 05 Sep 2020.

Submit your article to this journal $\pi$

Џلll Article views: 2

Q View related articles $\sqsubset$

View Crossmark data 4 


\title{
Short Note
}

\section{Cadmium and lead levels in three freshwater fish species from the Zambezi region, Namibia}

\author{
O Madzingira ${ }^{1 *}$ (D), LZ Lifumbela1 ${ }^{1}$ E Kandiwa² (iD, L Kandjengo³ (iD) and B Mushonga² (iD) \\ ${ }^{1}$ Department of Animal Health, University of Namibia, Katima Mulilo, Namibia \\ ${ }^{2}$ Department of Biomedical Sciences, University of Namibia, Neudamm, Namibia \\ ${ }^{3}$ Department of Fisheries and Aquatic Sciences, Sam Nujoma Campus, University of Namibia, Henties Bay, Namibia \\ *Correspondence: omuzembe@gmail.com
}

\begin{abstract}
Muscle tissue from three-spotted tilapia (Oreochromis andersonii) $(n=11)$, sharp tooth catfish (Clarias gariepinus) ( $n=14)$ and tigerfish (Hydrocynus vittatus) $(n=12)$ were sampled from a market in the Zambezi region, Namibia in June 2018 and analysed for cadmium and lead. Cadmium was not detected in the three fish species. Mean lead levels in all three fish species $\left(0.09-0.19 \mathrm{mg} \mathrm{kg}^{-1}\right)$ were below the recommended safe level of $0.3 \mathrm{mg} \mathrm{kg}^{-1}$. Catfish had the highest mean lead concentrations, followed by tigerfish and tilapia in descending order. However, the differences in mean lead concentrations between the three fish species were not statistically significant (ANOVA, $p=0.18$ ). These results show that the fish tested were safe for human consumption with respect to the metals tested. It is recommended that more metals and other contaminants, such as pesticides, be monitored robustly in water, sediment and fish, using the recommended protocols, in order to generate data that can be reliably used for human health risk assessments in the future.
\end{abstract}

Keywords: edible, fish muscle, river, sharp tooth catfish, three-spotted tilapia, trace metals, tigerfish

Fish are a cheaper and more readily available source of protein for resource poor communities around the world (Sayer and Cassman 2013), than other farmed sources of protein. Globally, approximately $21.4 \mathrm{~kg}$ of fish is consumed per capita (FAO 2010) per year. In Namibia, annual fish consumption per capita is between $10 \mathrm{~kg}$ and $12.1 \mathrm{~kg}$ (Tveldten et al. 1994; FAO 2016). Fishery is one of the major economic activities in the Zambezi region of Namibia (van der Waal. 2011; Tweddle and Hay 2012; Alexander 2013). Three major rivers in the Zambezi region, namely the Zambezi, Kwando/Linyati and Chobe Rivers provide a source of livelihood for the region's inhabitants.

Contamination and pollution of aquatic environments with metals from natural and anthropogenic sources are issues of public health concern worldwide (Ambedkar and Muniyan 2011) especially in areas, such as the Zambezi region of Namibia, where fish form a big part of the human diet and a source of livelihood. Approximately $82 \%$ of households in the region market fish (Tveldten et al. 1994).

The most common metals in fish are cadmium $(\mathrm{Cd})$, lead $(\mathrm{Pb})$ and mercury $(\mathrm{Hg})$, (FSAl 2009; Authman et al. 2015). Cadmium and lead toxicity in humans is most often linked to long-term consumption of fish (Castro-González and Méndez-Armenta 2008; WHO 2011; Bosch et al. 2016). These metals bioaccumulate, are very persistent in the environment (Ambedkar and Muniyan 2011; Baharom and Ishak 2015) and are bio-magnified along the food chain (MacFarlane and Burchett 2000). Bioaccumulation of cadmium in the kidneys can result in renal failure. Acute or chronic exposure to inorganic lead has been reported to cause cancer (Al-Busaidi et al. 2011; Rahman et al. 2012), neurologic (Charlet et al. 2012), cardiovascular (Bosch et al. 2016), haematological (Bosch et al. 2016; Leung et al. 2017) and teratogenic effects (McCluggage 1991; Al-Busaidi et al. 2011; Rahman et al. 2012; Piper and Restrepo 2013). Potential sources of metal pollution for aquatic systems are diverse and vary with geographical location. They include geologic weathering, erosion, direct atmospheric uptake, discharge of industrial, mining, residential, municipal and agricultural waste streams into rivers (Jabeen and Chaudhry 2010; Authman et al. 2015).

Because the major rivers of the Zambezi region course through many places and countries, toxic metals may be released or washed into the water polluting the aquatic environment and fish. The levels of metals in fish can be used to assess pollution in aquatic ecosystems and the safety of freshwater fish as a food source. Therefore, a cross-sectional study was carried out to assess the levels of cadmium and lead in the muscle of three freshwater fish species commonly consumed in the Zambezi region.

The study was carried out in Katima Mulilo town in the Zambezi region of Namibia (Figure 1). The region is located in the extreme north-east of the country $\left(17^{\circ} 49^{\prime} \mathrm{S}\right.$, $\left.23^{\circ} 57^{\prime} \mathrm{E}\right)$. It covers an area of approximately $14785 \mathrm{~km}^{2}$ and has a population of approximately 90596 (NSA 


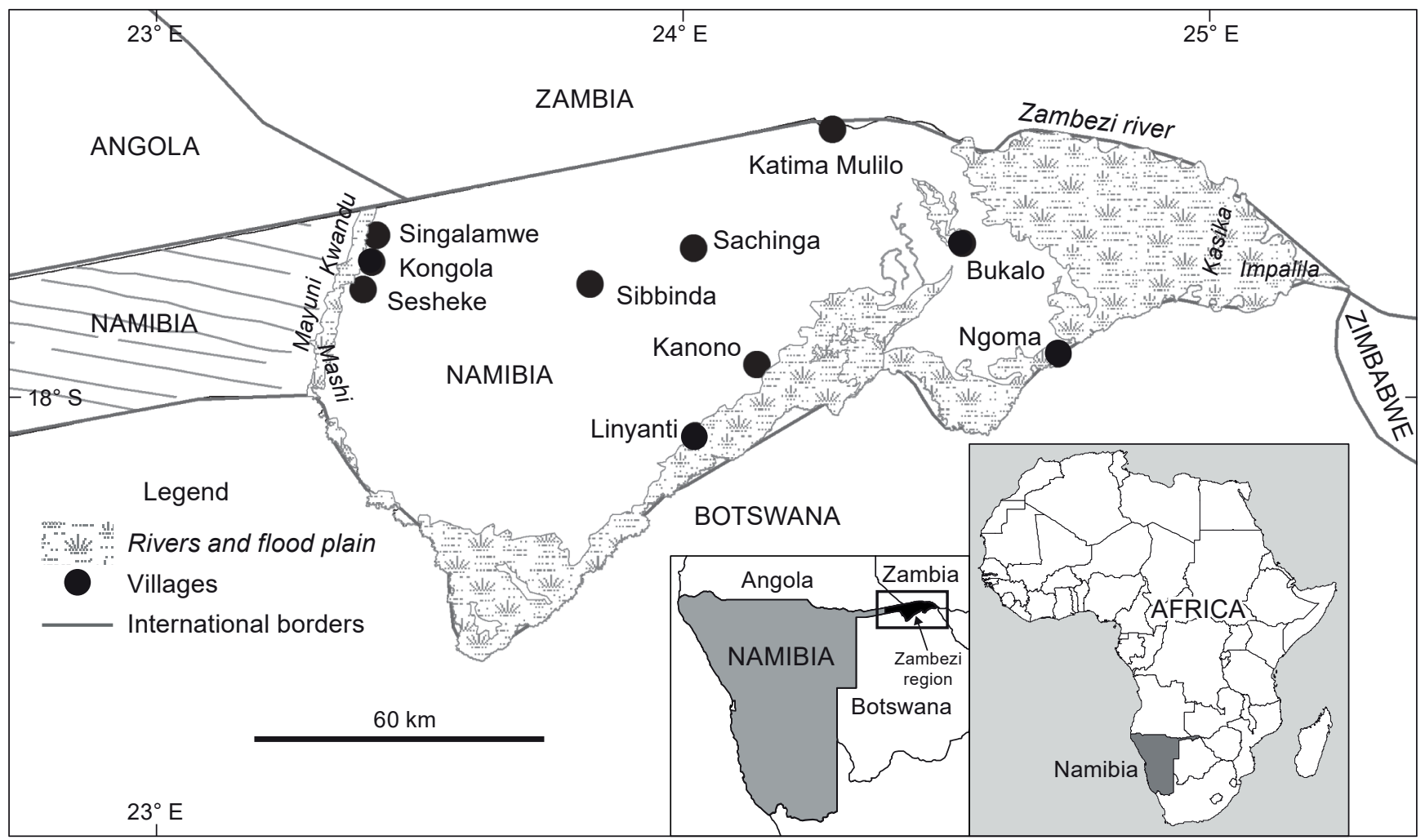

Figure 1: Location of Namibia (insert, right), the Zambezi region (insert, left) and villages and major rivers in the region (main)

2011). Three major rivers traverse the region, namely, the Zambezi, Kwando/Linyati and Chobe Rivers (Figure 1).

Three-spotted tilapia, Oreochromis andersonii (Castelnau, 1861) $(n=11)$, sharp tooth catfish, Clarias gariepinus (Burchell, 1822) $(n=14)$ and tigerfish, Hydrocynus vittatus (Castelnau, 1861) ( $n=12)$ were purchased from randomly selected fish traders at a popular fish market in Katima Mulilo town over a four-week period in June 2018. The fish were dispatched on ice to the University of Namibia laboratory (Katima Mulilo). Each fish specimen was identified to species level following the guidelines in Skelton (2001), labelled and weighed (g) and total length measured. Thereafter, each specimen was placed separately in a sterile polyethylene bag and stored frozen at $-20{ }^{\circ} \mathrm{C}$. Frozen fish specimens were dispatched to the Agricultural Laboratory (Windhoek) for analysis of cadmium and lead in muscle following the procedure of Bervoets and Blust (2003), using the Inductively Coupled Plasma Optimal Emission Spectrometer (ICP-OES, iCAP 6000 Series, Thermo Fischer Scientific, Bremen, Germany) on dried muscle. Drying was carried out at $70{ }^{\circ} \mathrm{C}$ in a forced-air drying oven until a constant weight was achieved. Standard reference materials from De Bruyn Spectroscopic Solutions (500MUL20-50 STD2) were used for quality assurance (QA) and quality control (QC), as per the manufacturer's recommendation. Each batch of samples was analysed with a blank and recoveries were within $10 \%$ certified values. Only reagents of a recognised analytical grade and double distilled deionised water were used for rinsing and dilutions. A Shapiro-Wilk test was used to test for normality of the data. ANOVA was used to test for the significance of differences in metal concentrations between fish species, where $p<0.05$ was considered statistically significant.

Cadmium was not detected in all three fish species. The highest mean lead levels were recorded in catfish $(0.96 \pm$ $\left.0.67 \mathrm{mg} \mathrm{kg}^{-1}\right)$, followed by tigerfish $\left(0.74 \pm 0.88 \mathrm{mg} \mathrm{kg}^{-1}\right)$ and tilapia $\left(0.45 \pm 0.30 \mathrm{mg} \mathrm{kg}^{-1}\right)$ in descending order, as shown in Table 1 and Figure 2. The variation in total body length and body weight followed the same pattern as lead concentrations, that is, catfish $>$ tigerfish > tilapia (Table 1). Lead levels in all three fish species were normally distributed as confirmed by the Shapiro-Wilk test $(W=0.93)$. Analysis of variance (ANOVA) revealed that there were no significant differences in lead concentrations between the catfish, tigerfish and tilapia $\left(F_{(2,34)}=1.77, p=0.18\right)$.

Cadmium contamination of rivers has been reported to originate from mining, industrial and agricultural sources, and the breakdown of the geological matrix in India (Ambedkar and Muniyan 2011; Ambedkar et al. 2017). The absence of mining activities (the latter are considered as one of the major contributors of cadmium) along the courses of the rivers in the Zambezi region (MacDonald, 2007) may explain the absence of cadmium in fish in this study. Previous studies in a number of freshwater fish species did not also detect cadmium (Addo-Bediako et al. 2014; Jooste et al. 2015; Garcia et al. 2016; Korkmaz et al. 2017). It has also been reported that cadmium has a lower bioaccumulation in fish muscle, compared with kidneys and livers (Chowdhury et al. 2004; Shinn et al. 2009; Jarić et al. 2011; El-Moselhy et al. 2014; Ahmad and Sarah 2015; Abarshi et al. 2017; Ibrahim et al. 2018; Rajeshkumar and 
Table 1: Mean cadmium and lead concentrations $( \pm S D)$ in catfish, tigerfish and tilapia

\begin{tabular}{lccc}
\hline Description & Catfish $(n=14)$ & Tigerfish $(n=12)$ & Tilapia $(n=11)$ \\
\hline Mean body weight $(\mathrm{g})$ & $520 \pm 79$ & $377 \pm 147$ & $251 \pm 33$ \\
Mean total body length (cm) & $41.6 \pm 6.53$ & $28.1 \pm 4.87$ & $22.2 \pm 2.25$ \\
Mean levels of lead $\left(\mathrm{mg} \mathrm{kg}^{-1}\right.$ dry weight) & $0.96 \pm 0.67$ & $0.74 \pm 0.88$ & $0.45 \pm 0.30$ \\
Mean levels of cadmium (mg kg dry weight) $^{-1}$ & 0 & 0 & 0 \\
\hline
\end{tabular}

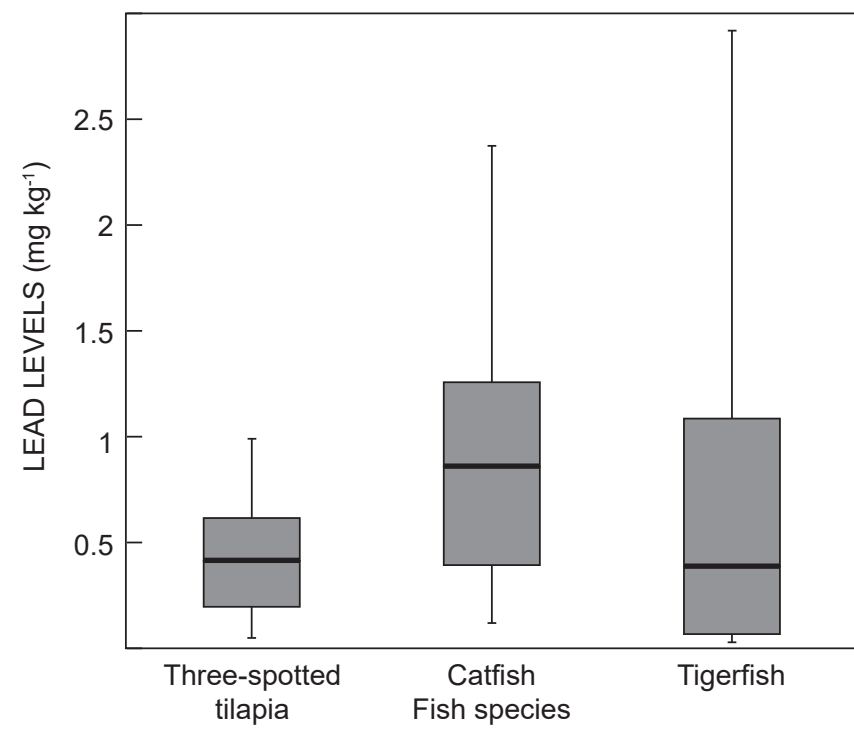

Figure 2: A comparison of lead concentrations between the three fish species from the Zambezi region.

Li 2018). The failure to detect cadmium in fish may be a reflection of the low level of contamination in river systems in the study area. Higher levels of cadmium are often reported in marine than in freshwater fish (Agwu et al. 2018).

Lead levels of $0.45-0.96 \mathrm{mg} \mathrm{kg}^{-1}$ (dry weight) were detected in the three fish species. Using a conversion factor of five (5) between dry and wet mass concentration (Magalhães et al. 2007; Harmelin-Vivien et al. 2009; Cossa et al. 2012; Bonito et al. 2016), the adjusted wet concentration of lead in fish muscle of $0.09-0.19$ $\mathrm{mg} \mathrm{kg}^{-1}$ was much lower than the levels of $1-1.2 \mathrm{mg}$ $\mathrm{kg}^{-1}$ determined for $O$. mossambicus in South Africa (Addo-Bediako et al. 2014), and below the Codex Alimentarius Commission (2015) recommended maximum safe level $\left(0.3 \mathrm{mg} \mathrm{kg}^{-1}\right)$ for long-term human consumption. Based on the Codex Alimentarius Commission standard on lead and cadmium levels, the fish sampled from the market were safe for human consumption. However, other studies have reported some health impacts of lead at very low concentrations, which puts into question the validity of lead thresholds (US-EPA 2004). Our findings suggest that cadmium and lead levels in river water were low, but additional studies are required to verify this assertion. Other studies in freshwater fish have reported lead levels many times higher than the acceptable maximum lead levels (Rose et al. 2015; Nevárez et al. 2015) especially in catfish (Jooste et al. 2015) and Oreochromis (Addo-Bediako et al. 2014). The contribution of industrial activities, municipal waste discharge and run-off from subsistence and intensive agricultural activities to lead contamination of river water and fish observed in this study is likely to be minimal, but cannot excluded, because the rivers course through a number of towns and countries.

Although lead concentrations were low and did not differ between the three fish species $(p=0.18)$, the omnivorous catfish had the highest mean lead levels $\left(0.96 \mathrm{mg} \mathrm{kg}^{-1}\right)$, which may be a reflection of the higher concentrations of metals on the riverbed, a habitat for catfish, as has been reported by other studies (Zhang et al. 2007; Leung et al. 2017). The feeding behaviour of catfish may have increased their chances of taking up lead contaminated food in the form of aquatic plants, invertebrates and small fish, compared with specialised feeders, such as tilapia (herbivorous). As a predator fish species at the top of the aquatic food chain, tigerfish were expected to accumulate more lead than catfish (Jarić et al. 2011). It is speculated that tigerfish grow faster than the accumulation of lead or that their rate of excretion of lead is faster. However, the fact that tigerfish in our study were smaller than catfish may explain the unexpected finding. As expected, tilapia, a predominantly herbivorous fish species at a lower trophic level on the aquatic food chain (Jarić et al. 2011), had the lowest levels of lead $\left(0.45 \mathrm{mg} \mathrm{kg}^{-1}\right)$. Results of this study suggest that a diet based on tilapia may be safer than a diet that contains catfish or tigerfish.

The failure to detect cadmium and the low lead levels detected in fish in this study suggest that the river systems and the fish sourced from them contain insignificant levels of cadmium and lead. This study, although utilising a smaller sample size, provides baseline data for future studies on trace metal and other contamination in fish and for human health risk assessments in the Zambezi region.

Acknowledgments - We are grateful to the University of Namibia for availing facilities and time for this study. We are also indebted to Mr K Shiningavamwe (Agriculture Scientific Officer) and his team in the Agricultural Laboratory of the Ministry of Agriculture, Water and Forestry of Namibia for assistance with the laboratory work.

\section{ORCID}

O Madzingira: https://orcid.org/0000-0003-1145-9880

E Kandiwa: https://orcid.org/0000-0003-0424-3002

L Kandjengo: https://orcid.org/0000-0002-9168-4676

B Mushonga: https://orcid.org/0000-0003-1062-2201

\section{References}

Abarshi MM, Dantala EO, Mada SB. 2017. Bioaccumulation of heavy metals in some tissues of croaker fish from oil spilled 
rivers of Niger Delta region. Nigeria. Asian Pacific Journal of Tropical Biomedicine 7: 563-568. https://doi.org/10.1016/j. apjtb.2017.05.008.

Addo-Bediako A, Marr SM, Jooste A, Luus-Powell WJ. 2014. Are metals in the muscle tissue of Mozambique tilapia a threat to human health? A case study of two impoundments in the Olifants River, Limpopo Province, South Africa. Annales de Limnologie: International Journal of Limnology 50: 201-210. https://doi org/10.1051/limn/2014091.

Agwu KK, Okoye CMI, Okeji MC, Clifford EO. 2018. Potential health impacts of heavy metal concentrations in fresh and marine water fishes consumed in Southeast, Nigeria. Pakistan Journal of Nutrition 17: 647-653. https://doi.org/10.3923/pjn.2018.647.653.

Ahmad AK, Sarah A. 2015. Human health risk assessment of heavy metals in fish species collected from catchments of former tin mining. International Journal of Research Studies in Science, Engineering and Technology 2: 9-21.

Al-Busaidi M, Yesudhason P, Al-Mughairi S, Al-Rahbi WAK, Al-Harthy KS, Al-Mazrooei NA. 2011. Toxic metals in commercial marine fish in Oman with reference to national and international standards. Chemosphere 85: 67-73. https://doi.org/10.1016/j. chemosphere.2011.05.057.

Alexander A. 2013. Evaluation of some heavy metals in certain fish, meat and meat products in Saudi Arabian markets. Egyptian Journal of Aquatic Research 38: 45-49.

Ambedkar G, Muniyan M. 2011. Bioaccumulation of some heavy metals in the selected five freshwater fish from Kollidam River, Tamilnadu, India. Advances in Applied Science Research 2 221-225.

Ambedkar G, Kmalakkannan J, Muniyan M. 2017. Assessment of some heavy metals in the selected freshwater fish species collected from Veeranam Lake Cuddalore District, Tamil Nadu, India. World Scientific News 81: 235-245.

Authman MM, Zaki MS, Khallaf EA, Abbas HH. 2015. Use of fish as bio-indicator of the effects of heavy metals pollution. Journal of Aquaculture Research and Development 6: 1-13. https://doi. org/10.4172/2155-9546.1000328.

Baharom ZS, Ishak MY. 2015. Determination of heavy metal accumulation in fish species in Galas River, Kelantan and Beranang mining pool, Selangor. Procedia Environmental Sciences 30: 320-325. https://doi.org/10.1016/j.proenv.2015.10.057.

Bervoets L, Blust R. 2003. Metal concentrations in water, sediment and gudgeon (Gobio gobio) from a pollution gradient: relationship with fish condition factor. Environmental Pollution 126: 9-19. https://doi.org/10.1016/S0269-7491(03)00173-8.

Bonito LT, Hamdoun A, Sandin SA. 2016. Evaluation of the global impacts of mitigation on persistent, bioaccumulative and toxic pollutants in marine fish. PeerJ 4: e1573. https://doi.org/10.7717/ peerj.1573.

Bosch AC, O'Neill B, Sigge GO, Kerwath SE, Hoffman LC. 2016. Heavy metals in marine fish and consumer health: a review. Journal of the Science of Food and Agriculture 96: 32-48. https:// doi.org/10.1002/jsfa.7360.

Castro-González MI, Méndez-Armenta M. 2008. Heavy metals: implications associated to fish consumption. Environmental Toxicology and Pharmacology 26: 263-271. https://doi. org/10.1016/j.etap.2008.06.001.

Charlet L, Chapron Y, Faller P, Kirsch R, Stone AT, Baveye PC. 2012. Neurodegenerative diseases and exposure to the environmental metals $\mathrm{Mn}, \mathrm{Pb}$, and $\mathrm{Hg}$. Coordination Chemistry Reviews 256: 2147-2163. https://doi.org/10.1016/j. ccr.2012.05.012

Chowdhury MJ, McDonald DG, Wood CM. 2004. Gastro-intestinal uptake and fate of cadmium in rainbow trout acclimated to sublethal dietary cadmium. Aquatic Toxicology (Amsterdam, Netherlands) 69: 149-163. https://doi.org/10.1016/j.aquatox.2004.05.002.

Codex Alimentarius Commission (CAC). 2015. General standard for contaminants and toxins in food and feed. CXS 193-1995. Geneva: FAO/WHO

Cossa, D, Harmelin-Vivien M, Mellon-Duval C, Loizeau V, Averty B, Crochet S, Chou L, Cadiou JF. 2012. Influence of bioavailability, trophic position, and growth on methylmercury in hakes (Merluccius merluccius) from Northwestern Mediterranean and Northeast Atlantic. Environmental Science \& Technology 46: 4885-4893. https://doi.org/10.1021/es204269w.

El-Moselhy KM, Othman Al, Abd El-Azem H, El-Metwally MEA. 2014. Bioaccumulation of heavy metals in some tissues of fish in the Red Sea, Egypt. Egyptian Journal of Basic and Applied Science 1: 97-105. https://doi.org/10.1016/j.ejbas.2014.06.001.

Food and Agriculture Organisation (FAO). 2010. The international fish trade and world fisheries. Available at http://www.fao.org/ fileadmin/user_upload/newsroom/docs/facts_sheet_fish_trade_ en.pdf. [Accessed 20 March 2019].

Food and Agriculture Organisation (FAO). 2016. Fishery and aquaculture statistics. Available at http://www.fao.org/3/i9942t/ 19942T.pdf. [Accessed 20 March 2019].

Food Safety Authority of Ireland (FSAI). 2009. Mercury, lead, cadmium, tin and arsenic in food. Toxicology Fact Series. Available at https://www.fsai.ie/WorkArea/DownloadAsset.aspx?id=8412. [Accessed 28 July 2018].

Garcia GG, Miguel EJL, Gabriel MAL, Mingala CN. 2016. The corollary effect of heavy metal accumulation in freshwater ponds on the hematological profile of Nile tilapia (Oreochromis niloticus). Environmental and Experimental Biology 14: 69-73. https://doi.org/10.22364/eeb.14.10.

Harmelin-Vivien M, Cossa D, Crochet S, Bănaru D, Letourneur Y, Mellon-Duval C. 2009. Difference of mercury bioaccumulation in red mullets from the north-western Mediterranean and Black Seas. Marine Pollution Bulletin 58: 679-685. https://doi. org/10.1016/j.marpolbul.2009.01.004.

Ibrahim D, Ibrahim AS, Paul ED, Umar M, Zannah UAS. 2018. Determination of some heavy metal content in tilapia and catfish species in Lake Njuwa, Adamawa State, Nigeria. Journal of Applied Science \& Environmental Management 22: 1159-1165. https://doi.org/10.4314/jasem.v22i8.3.

Jabeen F, Chaudhry AS. 2010. Environmental impacts of anthropogenic activities on the mineral uptake in Oreochromis mossambicus from Indus River in Pakistan. Environmental Monitoring and Assessment 166: 641-651. https://doi.org/10.1007/ s10661-009-1029-z.

Jarić I, Visnjic-Jeftic Z, Cvijanovic G, Gacic Z, Jovanovic L, Skoric $S$, Lenhardt M. 2011. Determination of differential heavy metal and trace element accumulation in liver, gills, intestine and. muscle of sterlet (Acipenser ruthenus) from Danube River in Serbia by ICP-OES. Microchemistry Journal 98: 77-81. https:// doi.org/10.1016/j.microc.2010.11.008.

Jooste A, Marr SM, Addo-Bediako A, Luus-Powell WJ. 2015. Sharptooth catfish shows its metal: a case study of metal contamination at two impoundments in the Olifants River, Limpopo river system, South Africa. Ecotoxicology and Environmental Safety 112: 96-104. https://doi.org/10.1016/j.ecoenv.2014.10.033.

Korkmaz C, Ay Ö, Çolakfakioğlu C, Cicik B, Erdem C. 2017. Heavy metal levels in muscle tissues of Solea solea, Mullus barbatus, and Sardina pilchardus marketed for consumption in Mersin, Turkey. Water, Air and Soil Pollution 228: 315. https://doi. org/10.1007/s11270-017-3503-5.

Leung HM, Duzgoren-Aydin NS, Au CK, Krupanidhi S, Fung KY, Cheung KC, Wong YK, Peng XL, Ye ZH, Yung KKL, et al. 2017. Monitoring and assessment of heavy metal contamination in a constructed wetland in Shaoguan (Guangdong Province, China): bioaccumulation of $\mathrm{Pb}, \mathrm{Zn}, \mathrm{Cu}$ and $\mathrm{Cd}$ in aquatic and terrestrial components. Environmental Science and Pollution Research International 24: 9079-9088. https://doi.org/10.1007/ s11356-016-6756-4. 
MacDonald EM. 2007. Integrated water resources management strategy for the Zambezi River Basin. Lusaka: SADC and ZRA. p 217.

Macfarlane GB, Burchett MD. 2000. Cellular distribution of copper, lead and zinc in the Grey Mangroove Avicemmia marina (Forsk.) Vierh. Aquatic Botany 68: 45-59. https://doi.org/10.1016/ S0304-3770(00)00105-4.

Magalhães MC, Costa V, Menezes GM, Pinho MR, Santos RS, Monteiro LR. 2007. Intra-and inter-specific variability in total and methylmercury bioaccumulation by eight marine fish species from the Azores. Marine Pollution Bulletin 54: 1654-1662. https:// doi.org/10.1016/j.marpolbul.2007.07.006.

McCluggage D. 1991. Heavy Metal Poisoning. NCS Magazine. Columbus: The Bird Hospital.

Nevárez M, Leal LO, Moreno M. 2015. Estimation of seasonal risk caused by the intake of lead, mercury and cadmium through freshwater fish consumption from urban water reservoirs in arid areas of northern Mexico. International Journal of Environmental Research and Public Health 12: 1803-1816. https://doi. org/10.3390/ijerph120201803.

NSA. 2011. Zambezi 2011 Census Regional Profile. Available at https://cms.my.na/assets/documents/ p19dptss1r10ksklnraqk5ne2jd.pdf [Accessed 21 April 2019].

Piper D, Restrepo JFC. 2013. Lead and cadmium: priorities for action from UNEP's perspective for addressing risks posed by these two heavy metals. E3S Web of Conferences 1: 30004

Rahman MS, Molla AH, Saha N, Rahman A. 2012. Study on heavy metals levels and its risk assessment in some edible fishes from Bangshi River, Savar, Dhaka, Bangladesh. Food Chemistry 134: 1847-1854. https://doi.org/10.1016/j.foodchem.2012.03.099.

Rajeshkumar S, Li X. 2018. Bioaccumulation of heavy metals in fish species from the Meiliang Bay, Taihu Lake, China. Toxicology Reports 5: 288-295. https://doi.org/10.1016/j. toxrep.2018.01.007.

Rose M, Fernandes A, Mortimer D, Baskaran C. 2015. Contamination of fish in UK fresh water systems: risk assessment for human consumption. Chemosphere 122: 183-189. https://doi.org/10.1016/j.chemosphere.2014.11.046.

Sayer J, Cassman KG. 2013. Agricultural innovation to protect the environment. Proceedings of the National Academy of Sciences 110: 8345-8348. https://doi.org/10.1073/pnas.1208054110.

Shinn CA, Dauba F, Grenouillet G, Guenard G, Lek S. 2009. Temporal variation of heavy metal contamination in fish of the river lot in southern France. Ecotoxicology and Environmental Safety 72: 1957-1965. https://doi.org/10.1016/j.ecoenv.2009.06.007.

Skelton PH. 2001. A complete guide to the freshwater fishes of southern Africa. (2nd ed.). Cape Town: Struik publishers. p 395.

Tveldten I, Girvan L, Maasdorp M, Pomuti A, van Rooy, G. 1996. Freshwater fisheries and fish management in Namibia: socio-economic background study. SSD Research Report no. 12. Windhoek: University of Namibia. Multi-Disciplinary Research Centre.

Tweddle D, Hay CJ. 2012. Integrated co-management of the Zambezi/Chobe river fisheries resources. Technical Report No. MFMR/NNF/WWF/Phasell/8. Windhoek: Ministry of Fisheries and Marine Management. p 98.

US-EPA. 2004. Intergrated Risk Information System (IRIS). Lead and compounds (inorganic) (CASRN 7439-92-1). Cincinnati, OH: United States Environmental Protection Agency, Environmental Criteria and Assessment Office,

van der Waal BCW, Hay CJ, Næsje, TF. 2011. The Katima Mulilo fish market data analysis, November 2007-May 2009. Technical Report no. MFMR/NNF/WWF/Phase II/2, 2011. Windhoek: Ministry of Fisheries and Marine Management. $p 43$.

World Health Organisation (WHO). 2011. Guidelines for drinking water quality. (4th ed). Geneva: World Health Organisation.

Zhang Z, Li H, Jin L, Zhen-bin W. 2007. Analysis of heavy metals of muscle and intestine tissue in fish - in Banan Section of Chongqing from Three Gorges Reservoir, China. Polish Journal of Environmental Studies 16: 949-958. 